\title{
Electrochemical Evaluation of Some Mg-Ca-Mn-Zr Biodegradable Alloys
}

\author{
BOGDAN ISTRATE ${ }^{1}$, CORNELIU MUNTEANU²*, ROMEU CHELARIU², DUMITRU MIHAI ${ }^{1 *}$, RAMONA CIMPOESU², \\ FLORIN SANDU VILLE TUDOSE ${ }^{1}$ \\ ${ }^{1}$ Technical University of Iasi, Mechanical Engineering Department, 61-63 D. Mangeron Blvd, 700050, lasi, Romania \\ ${ }^{2}$ Technical University of Iasi, Materials Science and Engineering Department, 41 D.Mangeron Blvd, 700050, Iasi, Romania
}

\begin{abstract}
Biodegradable magnesium alloys represent a class of materials with high properties that are used in a wide range of fields, such as medicine, aeronautics and automotive. Alloying the Mg-based alloys with small percentages of elements such as $\mathrm{Ca}, \mathrm{Mn}$ and $\mathrm{Zr}$ can conduct to the obtaining of some materials that can be the basis for the development of orthopedic implants. Calcium contributes to the formation of the $\mathrm{Mg}{ }_{2} \mathrm{Ca}$ lamellar compound, low concentrations of zirconium helps the microstructure refinement and corrosion resistance and the alloying with manganese leads to the increase of the mechanical characteristics.In this paper, the electrochemical behaviour of four biodegradable alloys from the Mg-Ca-Mn-Zr system was evaluated, with variable concentrations (0.5\%-1\%) of Mn, respectively Zr. Alloying the system with $1 \%$ of each element ( $\mathrm{Ca}, \mathrm{Mn}, \mathrm{Zr}$ ) led to the obtaining of the alloy with the highest corrosion resistance and the lowest degradation rate.
\end{abstract}

\section{Keywords: biodegradable alloys, microstructure, electrochemical analysis}

Mg-based biodegradable alloys have the advantage of high biocompatibility, osteointegration and good mechanical properties. Compared to other biocompatible alloys, some titanium alloys or stainless steels, biodegradable alloys have a similar Young modulus to biological bone [1,2]. Following previous research in the metallic biomaterials field and orthopedic implants, it was considered that biodegradable magnesium alloys are the best solution for the implantation of the implants used in ankle, foot surgery and the small joints of the extremities. The researches for magnesium alloys were previously focused for aeronautical industry, but now the studies are strongly increasing for experiments as implant materials [3].

Mg-Zr alloys have a high damping capacity (about $80 \%$ ), which helps the vibration improvement generated by the load and movement at the implant / bone interface [4]. Zirconium element contributes to refining the microstructure in magnesium alloys and increasing the mechanical properties. Also the effect of Fe impurities on the corrosion resistance decreases. Some researchers inserted $1 \% \mathrm{Zr}$ content and observed that the corrosion resistance is improving [5]. Manganese ( $\mathrm{Mn}$ ) is commonly used as a secondary element in magnesium-based alloys. It was showen that the grain size decreases with the increase of $\mathrm{Mn}$ content in the Mg-Al-Mn alloy, but at concentrations greater than $0.4 \%$ this effect stops [6]. It has also been reported that the tensile strength and fatigue strength of the extruded alloys AZ31, AZ61 and AZ21 can be improved [6]. Song et al. suggested that Mn performes corrosion resistance in $\mathrm{Mg}$ alloys containing $\mathrm{Al}$ by transforming $\mathrm{Fe}$ and other impurities into harmless intermetallic compounds [7]. Calcium (Ca) is the most abundantmineral in the human body, accounting for about $2 \%$ of body weight. Most of that, $99 \%$, is found in bones and teeth, where it has a structural role, while magnesium is the fourth mineral in the human body, participating in more than 300 metabolic processes in the human body. A recent study identified the size and shape of the compounds that are formed in the structure of materials significantly contributes to corrosion resistance [8], and for a low degradation, the percentage of calcium should be between
$0.6 \%$ and $1 \%$, [9]. Also Rad et al. presented that $\mathrm{Mg}_{2} \mathrm{Ca}$ eutectic compound in binary $\mathrm{Mg}$ - alloys could show low corrosion resistance depending on the calcium percentage in the alloy $[10,11]$.

Zhou et al have identified the following related alloys $\mathrm{Mg}-\mathrm{Zr}-\mathrm{Ca}$ : refined microstructure zirconium and magnesium grain remain relatively uniformly distributed in separate clusters. Hot-rolled Mg-Zr-Ca alloys have a higher compression strength compared to the cast alloy from the same system. Low concentrations of zirconium and calcium, respectively $0.5 \% \mathrm{Zr}$ and $1 \%$ Ca reveal an increased corrosion resistance, $\mathrm{Mg}-0.5 \mathrm{Zr}-1 \mathrm{Ca}$ and $\mathrm{Mg}-1 \mathrm{Zr}$ 1 Ca alloys have superior mechanical properties, corrosion resistance and good biocompatibility [12].

\section{Experimental part}

Materials and methods

Magnesium master alloys were used with $\mathrm{Ca}$ (Mg-15\% $\mathrm{Ca}), \mathrm{Zr}(\mathrm{Mg}-25 \% \mathrm{Zr}), \mathrm{Mn}(\mathrm{Mg}-3 \% \mathrm{Mn})$ and $99.7 \%$ pure technical magnesium alloy [13]. Graphite cylindrical crucibles with the following dimensions were used: outer diameter: $30 \mathrm{~mm}$, inner diameter: $22 \mathrm{~mm}$ and height : 60 $\mathrm{mm}$. The estimated charge calculation for filling the crucibles was about 20 grams. Table 1 shows the charge calculation for the master alloys quantities used for each elaborated mini ingot. During the melting operations, a vacuum atmosphere of $4.7 \times 10^{-3} \mathrm{mbar}$ was performed, followed by the purge of an inert gas enclosure (Ar). This operation was repeated three times in order to remove the air from the working chamber of the facility. The casting process of MgCaMnZr alloys was controlled, performed at a temperature of 700-710 $\mathrm{p} \mathrm{C}$ and maintained for $3 \mathrm{~min}$.

For the designed four experimental alloys, the following laboratory investigations were performed: elementary chemical composition with EDS system, structural characterization - by optical and electron microscopy Leica 5000 DMI microscope and SEM Quanta 200 3D microscope, structural compounds determination by X-ray diffraction - Xpert Pro XD X-ray diffractometer, with the following parameters: $\theta-2 \theta: 20^{\circ}-120^{\circ}$, step size $\left({ }^{\circ}\right)$ : 0.01313 , scan speed $(\% / \mathrm{s}): 0.0656, \mathrm{X}$-ray Copper $(\mathrm{K} \alpha)$ : $1.54156 \mathrm{~A}$. Electrochemical experiments were performed 


\begin{tabular}{|l|l|l|l|l|l|}
\hline $\begin{array}{l}\text { Nr. } \\
\text { Crt. }\end{array}$ & Experimental alloy & $\begin{array}{l}\text { Mg } \\
{[\mathrm{g}]}\end{array}$ & $\begin{array}{l}\text { Mg-15Ca } \\
{[\mathrm{g}]}\end{array}$ & $\begin{array}{l}\text { Mg-3Mn } \\
{[\mathrm{g}]}\end{array}$ & $\begin{array}{l}\mathrm{Mg}-25 \mathrm{Zr} \\
{[\mathrm{g}]}\end{array}$ \\
\hline 1 & $\mathrm{Mg}-1 \mathrm{Ca}-0.5 \mathrm{Mn}-0.5 \mathrm{Zr}$ & 14.94 & 1.33 & 3.33 & 0.4 \\
\hline $\mathbf{2}$ & $\mathrm{Mg}-1 \mathrm{Ca}-0.5 \mathrm{Mn}-1 \mathrm{Zr}$ & 14.54 & 1.33 & 3.33 & 0.8 \\
\hline 3 & $\mathrm{Mg}-1 \mathrm{Ca}-1 \mathrm{Mn}-0.5 \mathrm{Zr}$ & 11.60 & 1.33 & 6.67 & 0.4 \\
\hline 4 & $\mathrm{Mg}-1 \mathrm{Ca}-1 \mathrm{Mn}-1 \mathrm{Zr}$ & 11.20 & 1.33 & 6.67 & 0.8 \\
\hline
\end{tabular}

Table 1

CHARGE CALCULATION FOR THE 4 EXPERIMENTAL ALLOYS

\begin{tabular}{|c|c|c|c|c|c|}
\hline Alloy & & $\% M g$ & $\% \mathrm{Ca}$ & $\% M n$ & $\% \mathrm{Zr}$ \\
\hline \multirow{5}{*}{$\mathrm{Mg}-1 \mathrm{Ca}-0.5 \mathrm{Mn}-0.5 \mathrm{Zr}$} & Area 1 & 98.08 & 0.84 & 0.32 & 0.76 \\
\hline & Area 2 & 97.93 & 1.21 & 0.39 & 0.47 \\
\hline & Area 3 & 97.92 & 0.84 & 0.42 & 0.82 \\
\hline & Average & 97.98 & 0.96 & 0.38 & 0.68 \\
\hline & Standard Deviation & 0.9 & 0.21 & 0.05 & 0.19 \\
\hline \multirow{5}{*}{$\mathrm{Mg}-1 \mathrm{Ca}-0.5 \mathrm{Mn}-1 \mathrm{Zr}$} & Area 1 & 97.3 & 1.01 & 0.47 & 1.22 \\
\hline & Area 2 & 97.44 & 1.14 & 0.59 & 0.83 \\
\hline & Area 3 & 96.63 & 1.47 & 0.58 & 1.32 \\
\hline & Average & 97.12 & 1.21 & 0.55 & 1.12 \\
\hline & Standard Deviation & 0.43 & 0.24 & 0.07 & 0.26 \\
\hline \multirow{5}{*}{$\mathrm{Mg}-1 \mathrm{Ca}-1 \mathrm{Mn}-0.5 \mathrm{Zr}$} & Area 1 & 97.95 & 0.82 & 0.77 & 0.46 \\
\hline & Area 2 & 97.67 & 0.75 & 1 & 0.58 \\
\hline & Area 3 & 97.66 & 1.04 & 0.87 & 0.43 \\
\hline & Average & 97.76 & 0.87 & 0.88 & 0.49 \\
\hline & Standard Deviation & 0.16 & 0.15 & 0.12 & 0.08 \\
\hline \multirow{5}{*}{ Mg-1Ca-1Mn-1Zr } & Area 1 & 96.99 & 1.22 & 0.57 & 1.23 \\
\hline & Area 2 & 97.35 & 1.16 & 0.38 & 1.11 \\
\hline & Area 3 & 96.8 & 1.18 & 0.87 & 1.15 \\
\hline & Average & 97.05 & 1.19 & 0.61 & 1.16 \\
\hline & Standard Deviation & 0.28 & 0.03 & 0.25 & 0.06 \\
\hline
\end{tabular}

Table 2

CHEMICAL COMPOSITIONS OBTAINED BY EDS ANALYSIS IN DIFFERENT AREAS. on a potentiostat VoltaLab 201 in SBF electrolyte solution [14]: $\mathrm{Na}^{+}: 142, \mathrm{~K}^{+}: 5, \mathrm{Mg}^{2+}: 1.5, \mathrm{Ca}^{2+}: 2.5, \mathrm{Cl}^{-1}: 147.8, \mathrm{HCO}_{3}: 4.2$, HPO $2: 1, \mathrm{SO}_{4}^{2: 0.5}$.) with $\mathrm{pH}$ value of 7.01 . Table 2 presents the chemical composition of each experimental alloy.

\section{Results and discussions}

Microstructural analysis

The optical microscopy images are shown in Figure 1 , where the morphologies of magnesium grains, the arrangement of the lamellar eutectic at the grain boundaries of á-Mg and the appearance of segregation in the form of black-colored nests of the $\beta$-Zr element are shown. It can be concluded that increasing the amount of Zr content, respectively Mn content significantly decreases the size of the magnesium grain, improving the mechanical and corrosion resistance characteristics.
Scanning electron microscopy was obtained on the same samples used for EDS chemical analysis and optical microscopy, performing SEM images athigh magnification powers (500X / 2000X - figure 2). The lamellar appearance of the $\mathrm{Mg}_{2} \mathrm{Ca}$ eutectic compound is much better presented at the 2000X magnification, with a perfect adhesion with the magnesium grains. The bright white globular particles settle in clusters are relatively unevenly distributed and show formation of the $\beta$-Zr compound.

Figure 3 shows the X-ray patterns for the Mg-1Ca-XMn$y Z r$ experimental alloys. It was identified as predominant phase, $\alpha-M g$, having a hexagonal crystallographic structure. The $\alpha$-Mg compound, as major component phase was identified at $2 \theta=36.42^{\circ}, 58.12^{\circ}, 78.76^{\circ}$ and $96.54^{\circ}$. The phase $\mathrm{Mg}_{2} \mathrm{Ca}$ - hexagonal structure was

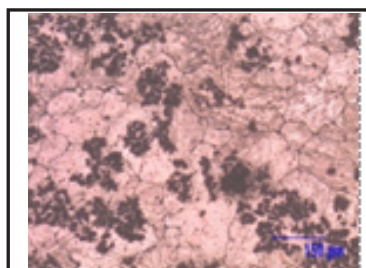

a) $100 \mathrm{X}$

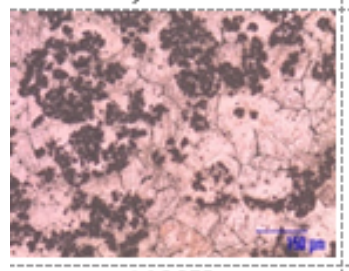

e) $100 \mathrm{X}$

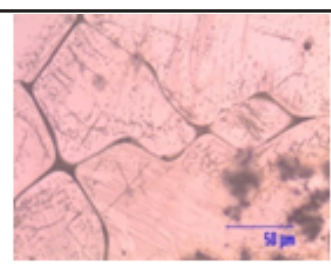

b) $500 \mathrm{X}$

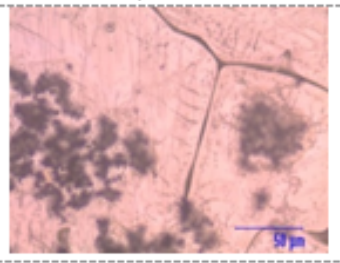

f) $500 \mathrm{X}$

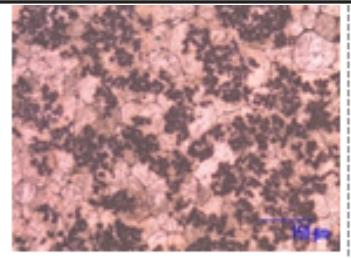

c) $100 \mathrm{X}$

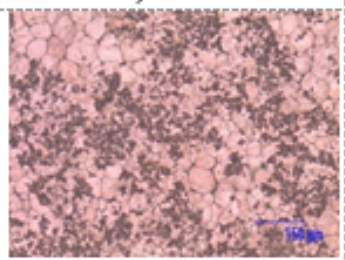

g) $100 \mathrm{X}$

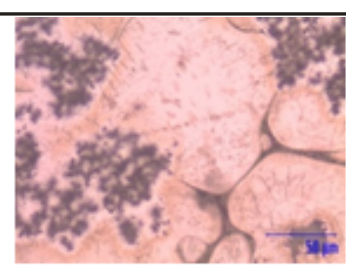

d) $500 \mathrm{X}$

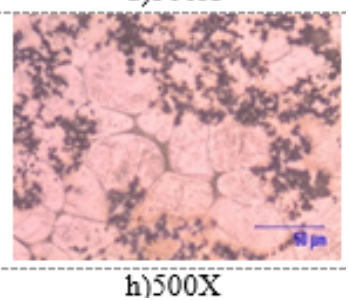

Fig.1. Optical microscopy images of the experimental alloys: a),b) Mg-1Ca-0.5Mn-0.5Zr; c),d) Mg-1Ca-0.5Mn-1Zr; e),f) Mg-1Ca-1Mn-0.5Zr; g),h) Mg-1Ca-1Mn-1Zr. 


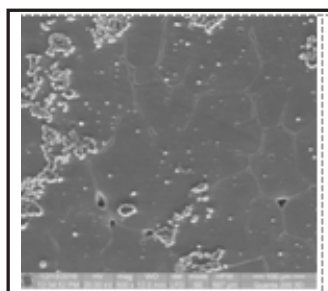

a) $500 \mathrm{X}$

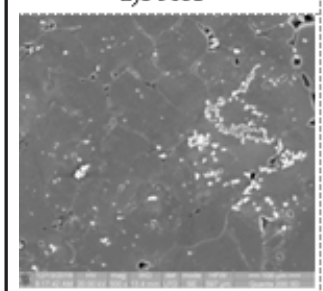

e) $500 x$

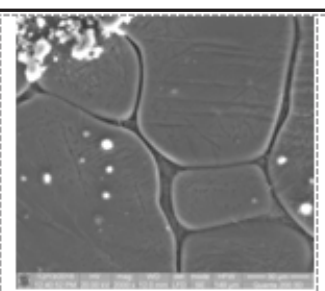

b) $2000 \mathrm{X}$

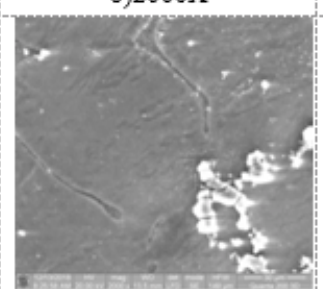

f) $2000 \mathrm{X}$

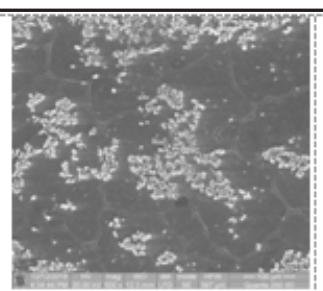

c) $500 \mathrm{X}$

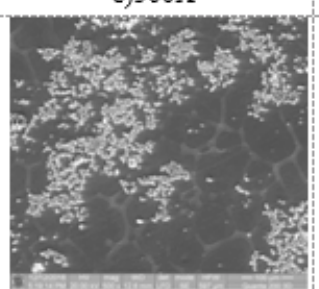

g) $500 \mathrm{X}$

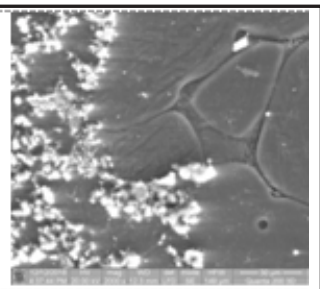

d) $2000 \mathrm{X}$

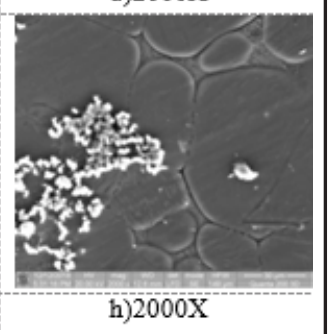

Fig. 2. Scanning electron

microscopy images of experimental alloys: a),b) Mg$1 \mathrm{Ca}-0.5 \mathrm{Mn}-0.5 \mathrm{Zr} ; \mathrm{c})$, d) Mg-1Ca$0.5 \mathrm{Mn}-1 \mathrm{Zr} ; \mathrm{e}$, f) Mg-1Ca-1Mn-0.5Zr; g),h) Mg-1Ca-1Mn-1Zr.

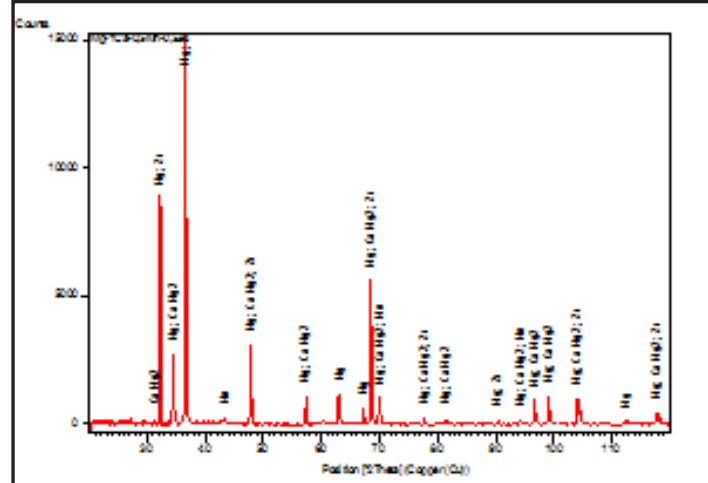

a) $\mathrm{Mg}-1 \mathrm{Ca}-0.5 \mathrm{Mn}-0.5 \mathrm{Zr}$

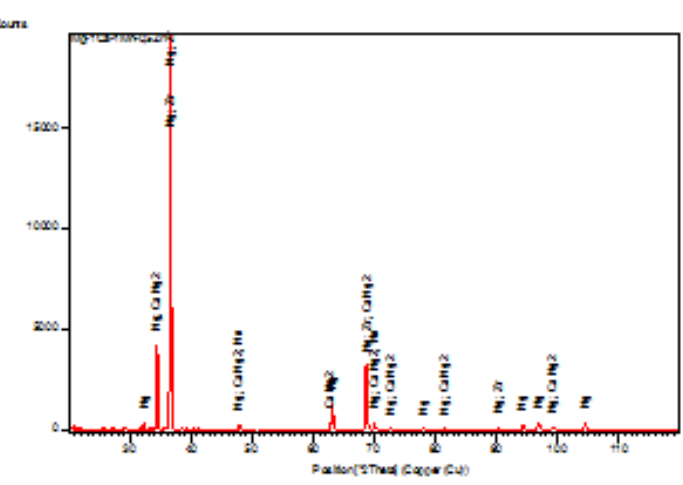

c) $\mathrm{Mg}-1 \mathrm{Ca}-0.5 \mathrm{Mn}-1 \mathrm{Zr}$

highlighted at $2 \theta=33.76^{\circ}, 52.38^{\circ}$ and $59.28^{\circ}$. The secondary constituents $\beta-Z r, \alpha-M n$ with hexagonal crystallographic structures, respectively cubic structure, were identified at the angles $24=36.54^{\circ}$, respectively $2 \theta$ $=43.11^{\circ}$.

\section{Electrochemical analysis}

Electrochemical experiments were performed at $37^{\circ} \mathrm{C}$ with continuous stirring of the SBF solution. The experimental parameters are presented in table 3. $1 \% \mathrm{Zr}$ alloys present a lower corrosion current by $35 \%$ compared to those with $1 \% \mathrm{Mn}$. The percentage variation of $\mathrm{Mn}$ in addition to the other two alloying elements, respectively $\mathrm{Ca}$ and $\mathrm{Zr}$, does not significant influence the electrocorrosion parameters, with small differences between Mg$1 \mathrm{Ca}-0.5 \mathrm{Mn}-1 \mathrm{Zr}$ and $\mathrm{Mg}-1 \mathrm{Ca}-1 \mathrm{Mn}-1 \mathrm{Zr}$. All alloys have anodic (ba) and cathodic (bc) reactions with similar intensities. The corrosion rates shown are higher than those recorded for the $\mathrm{Mg}-0.8 \mathrm{Ca}$ (1.08 $\mathrm{mm} /$ year) alloy [15], where the

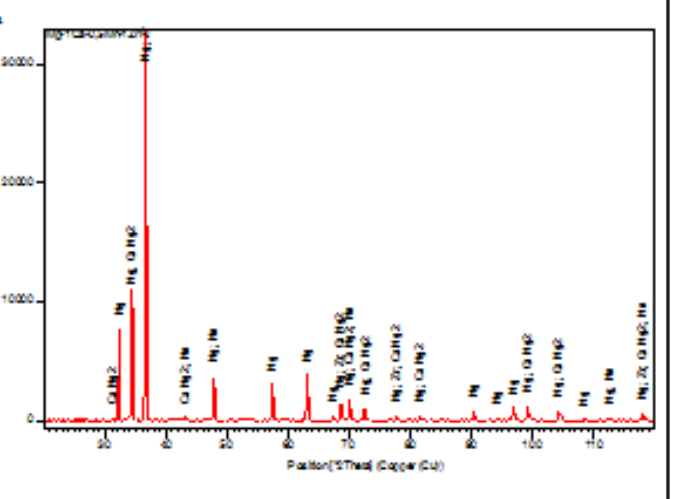

b) $\mathrm{Mg}-1 \mathrm{Ca}-1 \mathrm{Mn}-0.5 \mathrm{Zr}$

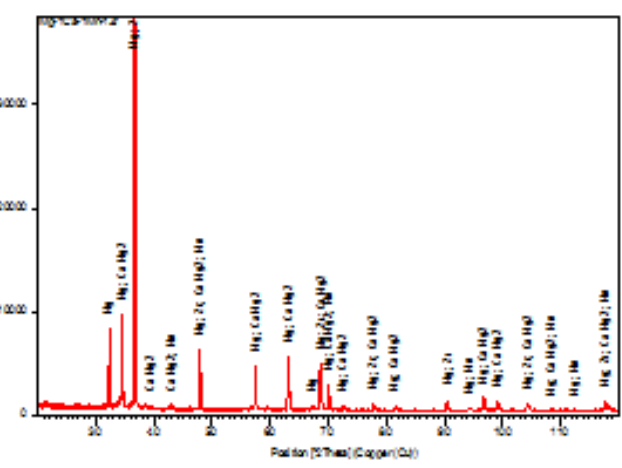

d) $\mathrm{Mg}-1 \mathrm{Ca}-1 \mathrm{Mn}-1 \mathrm{Zr}_{\mathrm{r}}$
Fig. 3. X-ray diffractograms of experimental alloys: a) Mg-1Ca-0.5Mn-0.5Zr; b) $\mathrm{Mg}-1 \mathrm{Ca}-1 \mathrm{Mn}-0.5 \mathrm{Zr}$; c) $\mathrm{Mg}-1 \mathrm{Ca}-0.5 \mathrm{Mn}-1 \mathrm{Zr}$; d) Mg-1Ca-1Mn-1Zr. 
Table 3

EXPERIMENTAL PARAMETERS OF ELECTRO-CORROSION TEST IN A SOLUTION OF SBF ELECTROLYTE

\begin{tabular}{|c|c|c|c|c|c|c|}
\hline Alloy & $\begin{array}{c}E_{0} \\
\mathrm{mV}\end{array}$ & $\begin{array}{c}\mathrm{b}_{2} \\
\mathrm{mV}\end{array}$ & $\begin{array}{c}\mathrm{b}_{\mathrm{s}} \\
\mathrm{mV}\end{array}$ & $\begin{array}{c}\mathrm{R}_{\mathrm{p}} \\
\mathrm{kohm} . \mathrm{cm}^{2}\end{array}$ & $\begin{array}{c}\mathrm{J}_{\text {cor }} \\
\mu \mathrm{A} / \mathrm{cm}^{2}\end{array}$ & $\begin{array}{c}V_{\text {osr }} \\
\mathrm{mm} / \mathrm{an}\end{array}$ \\
\hline $\mathrm{Mg}-1 \mathrm{Ca}-0.5 \mathrm{Mn}-0.5 \mathrm{Zr}$ & -1618.8 & 157.5 & -164.8 & 1.53 & 21.06 & 5.06 \\
\hline $\mathrm{Mg}-1 \mathrm{Ca}-0.5 \mathrm{Mn}-1 \mathrm{Zr}$ & -1598.7 & 180.4 & -184.3 & 1.94 & 15.96 & 3.84 \\
\hline $\mathrm{Mg}-1 \mathrm{Ca}-1 \mathrm{Mn}-0.5 \mathrm{Zr}$ & -1589.2 & 151.9 & -149.5 & 1.22 & 23.67 & 5.69 \\
\hline $\mathrm{Mg}-1 \mathrm{Ca}-1 \mathrm{Mn}-1 \mathrm{Zr}$ & -1464.3 & 147.3 & 140.3 & 1.46 & 15.85 & 3.81 \\
\hline
\end{tabular}

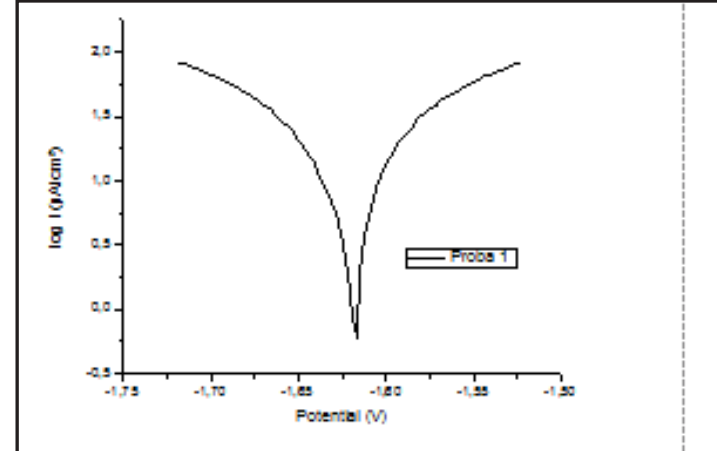

a)

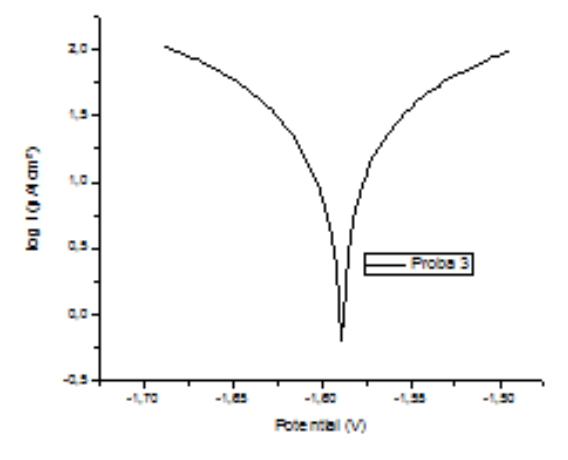

c)

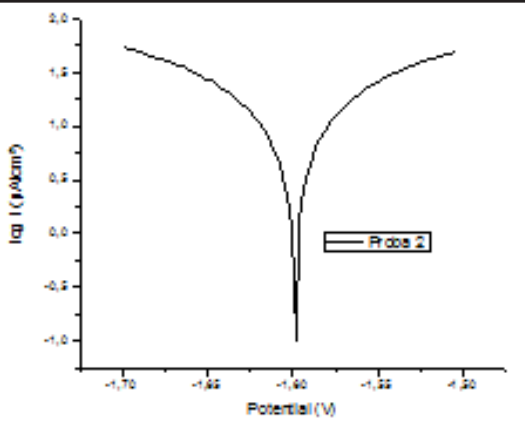

b)

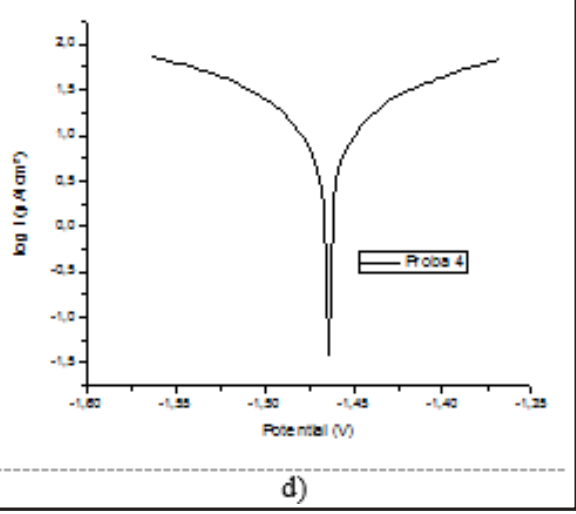

Fig. 4. Tafel diagrams for experimental alloys: a) MglCa0.5Mn0.5Zr; b) Mg1Ca0.5Mn1Zr; c) MglCa1Mn0,5Zr and d) Mg1Ca1Mn1Zr curves highlighting this aspect, figure 5 . The behavior is similar because all the experimental alloys are based on magnesium which is found in a very high content and will representively influence the behavior of the alloy to electrocorrosion test.

Based on the analysis of the open circuit potential (OCP), performed for 60 minutes it was observed that the experimental alloys have a lower tendency of passivation compared to pure $\mathrm{Mg}$ [15]. During the test, the experimental alloys present both the passivation stage of the surface by forming the passive layer of $\mathrm{Mg}(\mathrm{OH})$, and a repassivation after the initial layer has been through. The corrosion of the material has continued, the behavior is observed especially in Mg1Ca0,5Mn0,5Zr alloy, respectively MglCa1Mn0,5Zr. While scanning the cyclic diagrams, the materials exhibited an initial, uniform redox reaction without entering a passivation state (characterized by a minimum current density value that is close to zero). Overall the corrosion aspect, figure 6, present a generalized type, but this aspect in given by a summation of several pitting areas, which appear and are distributed over the entire surface of the alloys. The sharp increase of the current density shows the formation of pitting areas on the surface of the experimental alloy that are formed and spread very quickly leading to the generalization of the surface corrosion. During reverse scanning, the current density decreased again, indicating that the surface of the material was repassivated. The corrosion tracks were again covered with reaction compounds and in some cases disappeared by degrading the material from the surface and passing it into electrolyte solution.

The microstructural analysis of the surface of the experimental samples was performed by scanning electron microscopy. The cleaning step was aimed to eliminate the compounds with reduced stability formed on the surface of the alloy after contact with the electrolyte solution. Figure 6 shows the surfaces of the four experimental alloys after the electro-corrosion resistance test.

From the SEM analysis (figure 6), it was observed the generalized corrosion character of the surface of the experimental alloys with the compounds formation, confirming the corrosion character observed on the cyclic curve diagrams (figure 5). All the alloys have areas covered by the reaction compounds and less affected areas of corrosion. Mg1Ca1Mn1Zr alloy has the cleanest surface. This phenomenon is due to the presence of $\mathrm{Mn}$ and $\mathrm{Zr}$ elements, especially zirconium, which form stable oxides on the surface of the alloy and manage to protect it against electro-corrosion. The analyzed samples for corrosion resistance were subsequently washed in an ultrasonic bath in technical alcohol for $60 \mathrm{~min}$ in order to remove unstable reaction compounds from the surface and to highlight the corrosion surface. Table 4 gives the experimental results obtained from the chemical analysis of the surfaces of the experimental alloys after the ultrasonic cleaning step.

After the cleaning process, it is observed that all the compounds based on sodium have disappeared, the sodium element from the electrolyte solution had been 


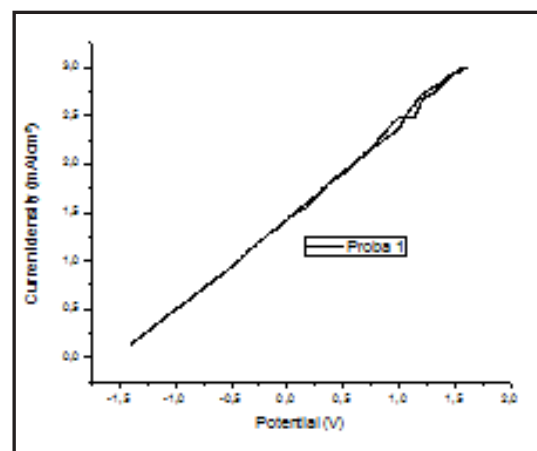

a)

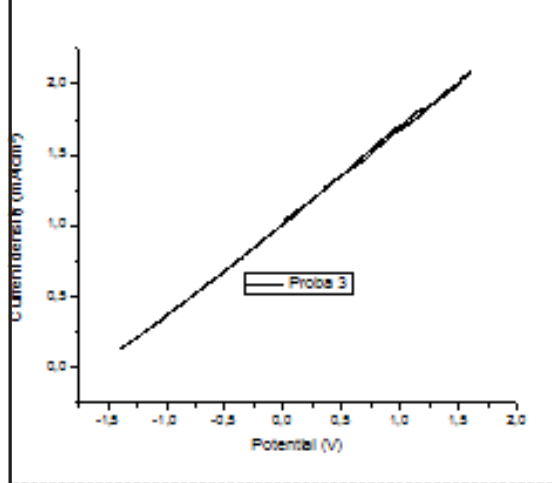

c)
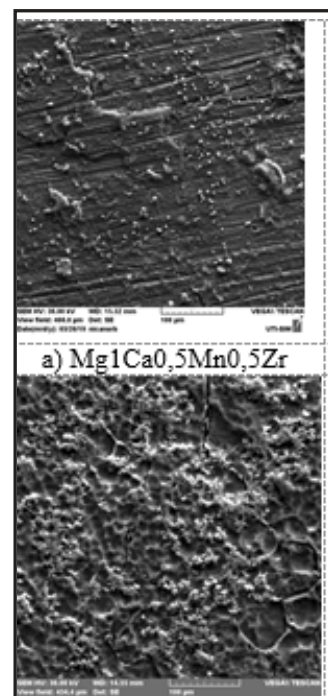

e) $\mathrm{Mg} 1 \mathrm{Ca} 0,5 \mathrm{Mn} 0,5 \mathrm{Zr}$

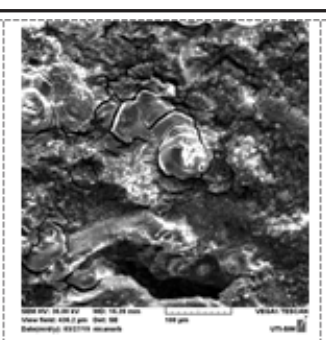

b) $\mathrm{Mg} 1 \mathrm{Ca} 0,5 \mathrm{Mn} 1 \mathrm{Zr}$

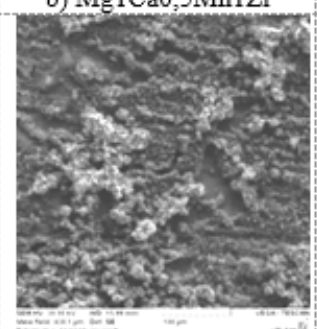

f) $\mathrm{Mg} 1 \mathrm{Ca} 0,5 \mathrm{Mn} 1 \mathrm{Zr}$

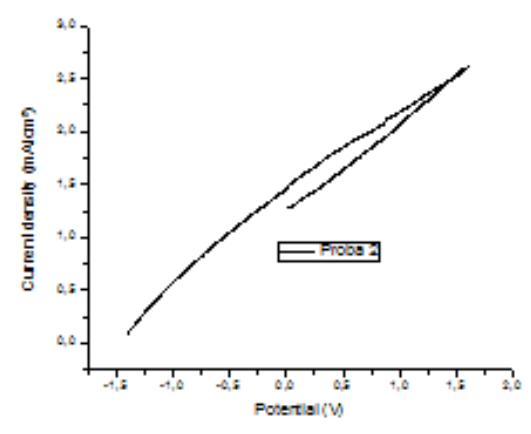

b)

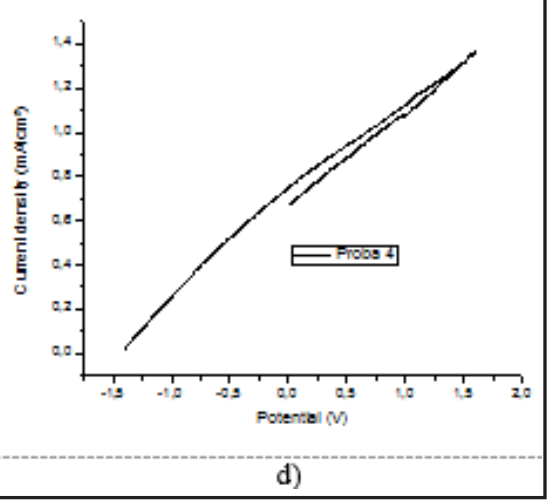

d)
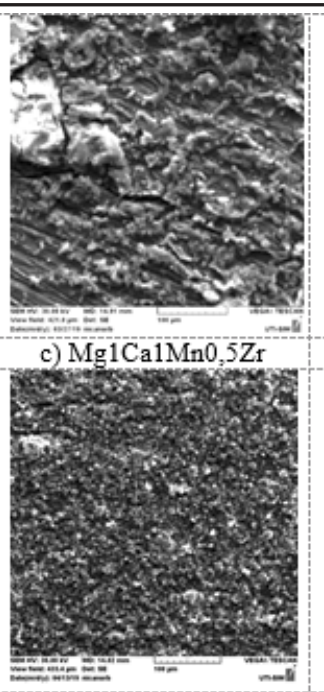

g) $\mathrm{Mg} 1 \mathrm{Ca} 1 \mathrm{Mn} 0,5 \mathrm{Zr}$

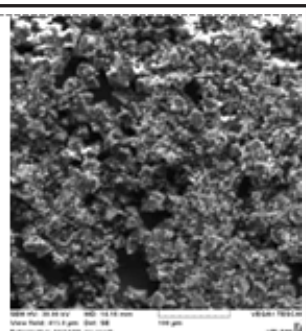

d) $\mathrm{Mg} 1 \mathrm{Ca} 1 \mathrm{Mn} 1 \mathrm{Zr}$

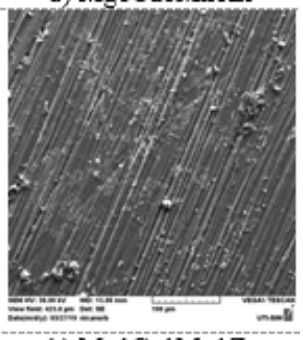

h) Mg1Ca1Mn1Zr
Fig. 6. Surfaces SEM images of the experimental alloys after the electro-corrosion resistance test: without ultrasonic cleaning (a), b), c) and d)) and with the ultrasonic cleaning (e), f), g) and h))

Table 4

CHEMICAL COMPOSITION OF THE EXPERIMENTAL ALLOYS SURFACE AFTER THE ELECTRO-CORROSION TEST IN SBF ELECTROLYTE SOLUTION AND AFTER ULTRASONIC CLEANING STEP (1-Mg1Ca0.5Mn0.5Zr; 2-Mg1Ca0,5Mn1ZR; 3-Mg1Ca1Mn0.5ZR; 4-Mg1Ca1Mn1Zr)

\begin{tabular}{|c|c|c|c|c|c|c|c|c|c|c|c|c|c|}
\hline \multirow{2}{*}{\multicolumn{2}{|c|}{ Alloy }} & \multicolumn{2}{|c|}{$\mathrm{Mg}$} & \multicolumn{2}{|c|}{$\mathrm{Ca}$} & \multicolumn{2}{|c|}{$\mathrm{Mn}$} & \multicolumn{2}{|c|}{$\mathrm{Zr}$} & \multicolumn{2}{|c|}{0} & \multicolumn{2}{|c|}{ C } \\
\hline & & wt $\%$ & at $\%$ & wt $\%$ & at $\%$ & wt $\%$ & at $\%$ & wt $\%$ & at $\%$ & wt $\%$ & at $\%$ & wt $\%$ & at $\%$ \\
\hline \multirow{2}{*}{1} & Aut & 77.5 & 69.87 & - & - & - & - & 1.88 & 0.45 & 17.44 & 23.88 & 3.18 & 5.81 \\
\hline & $\mathrm{El}$ & 79.01 & 72.86 & 0.65 & 0.36 & 0.32 & 0.13 & 2.01 & 0.49 & 16.06 & 22.50 & 1.96 & 3.66 \\
\hline \multirow{2}{*}{2} & Aut & 39.51 & 29.9 & 0.98 & 0.45 & - & - & - & - & 56.28 & 64.71 & 3.22 & 4.94 \\
\hline & El & 39.26 & 30.1 & 0.99 & 0.46 & 0.43 & 0.15 & 0.95 & 0.19 & 55.44 & 64.57 & 2.92 & 4.54 \\
\hline \multirow{2}{*}{3} & Aut & 36.01 & 27.03 & - & - & - & - & - & - & 63.99 & 72.97 & - & - \\
\hline & El & 16.5 & 11.58 & 0.2 & 0.2 & 0.17 & 0.005 & 0.44 & 0.08 & 82.69 & 88.19 & - & - \\
\hline 4 & Aut & 45.52 & 35.48 & - & - & - & - & - & - & 54.48 & 64.5 & - & - \\
\hline & EI & 45.01 & 35.54 & 0.32 & 0.15 & 0.34 & 0.12 & 0.98 & 0.21 & 53.35 & 63.98 & - & - \\
\hline & $\begin{array}{l}\text { Eroare } \\
\text { EDS\% }\end{array}$ & \multicolumn{2}{|c|}{1.5} & \multicolumn{2}{|c|}{0.03} & \multicolumn{2}{|c|}{0.03} & \multicolumn{2}{|c|}{0.06} & \multicolumn{2}{|c|}{2.01} & \multicolumn{2}{|c|}{0.5} \\
\hline
\end{tabular}


identified on all the surfaces of the experimental alloys. The Mg1Ca0.5Mn1Zr, MglCa1Mn0.5Zr, respectively Mg1Ca1Mn1Zr alloys presentan oxide layer on the surfaces that has not been removed in the cleaning stage and has not reached a very advanced degradation stage. In the case of Mg1Ca0.5Mn0,5Zr alloy, which was most strongly corroded, the oxide layer on the surface passed into solution. The surfaces of $\mathrm{MglCa} 0.5 \mathrm{Mn} 0.5 \mathrm{Zr}$ and $\mathrm{MglCa} 0.5$ $\mathrm{Mn1Zr}$ alloys are also identified the carbon element that participates in the formation of carbonates on the surface. The zirconium element forms a oxidation layer with good anti-corrosive properties which has a protective role of the alloy. In the case of Mg1Ca1Mn 0.5Zr alloy, a magnesium oxide was formed, which covers the entire surface of the material with a thickness of $5 \mu \mathrm{m}$.

\section{Conclusions}

Following the optical metallographic analysis, the scanning electron microscopy and the X-ray diffraction, the phases and alloy compounds belonging to the $\mathrm{Mg}-\mathrm{Ca}$ $\mathrm{Mn}-\mathrm{Zr}$ system were identified. These show the main phase $\alpha-M g$ with hexagonal structure, Zr- distributed into clusters, manganese dissolved in the intermetallic structure and $\mathrm{Mg}_{2} \mathrm{Ca}$ compound was identified at the boundary of magnesium grains having lamellar structure.

Alloys with the content of $1 \%$ Zr have a lower corrosion current by $35 \%$ compared to those with $1 \% \mathrm{Mn}$, aspects that are seen also in degradation rate of the alloys in millimeters per year. The percentage variation of $M n$ in addition to the other two alloying elements, respectively $\mathrm{Ca}$ and $\mathrm{Zr}$, does not greatly influence the electro-corrosion parameters, with small differences between Mg1Ca0.5Mn1Zr and Mg1Ca1Mn1Zr. All alloys have both anodic (ba) and cathodic (bc) reactions with similar intensities.

All alloys have areas covered by reaction compounds and areas less affected by corrosion process. Mg1Ca1Mn1Zr alloy has the cleanest surface. This phenomenon is due to the Mn and Zr elements, especially zirconium, which form stable oxides on the surface of the alloy and manage to protect it against electro-corrosion.

Acknowledgement:This work was supported by a research grant of TUIASI, projectnumber TUIASI-GI-2018-PN-III-P1-1.1-PD-2016-0430.

\section{References}

1.FEKRY, A.M., EL-SHERIF, R.M., Electrochemical corrosion behavior of magnesium and titanium alloys in simulated body fluid, Electrochim. Acta, 54, 2009, p. 7280.
2. BALTATU, MS; TUGUI, CA; PERJU, MC; BENCHEA, M; SPATARU, MC; SANDU, AV; VIZUREANU, P, Biocompatible Titanium Alloys used in Medical Applications, REVISTA DE CHIMIE, 70, no. 4, 2019, p. 1302.

3. ZENG, R., DIETZEL, W.G., WITTE, F., HORT, N., BLAWERT, C., Progress and challenge for magnesium alloys as biomaterials, J. Advanced Engineering Materials, 10, 2008 p. B3"B14.

4. TSAI, M.H., CHEN, M.S., LIN, L.H, LIN, M.H., WU, C.Y., OU, K.L., YU, C.H, Effect of heat treatment on the microstructures and damping properties of biomedical Mg-Zralloy, J ournal of Alloys and Compounds, 509, 2011, p. 813.

5. YUNCANG, L., CUIE, W., DOLLY, M., RAGAMOUNI, S., NEMANI, H., GOPAL, P., HODGSON, P., Mg-Zr-Sr alloys as biodegradable implant materials, Acta Biomaterialia, 8, 2012, p. 3177.

6. DING, Y., WEN, C., HODGSON, P., LI Y., Effects of alloying elements on the corrosion behaviour and biocompatibility of biodegradable magnesium alloys: a review, J .Mater. Chem. B, 2, 2014, p. 1912.

7. SONG, G.L., ATRENS, A., Corrosion mechanisms of magnesium alloys, Adv. Eng. Mater., 1, 1999, p. 11.

8. BAKHSHESHI-RAD, H.R., IDRIS, M.H., KADIR, M.R.A., FARAHANY, S. Microstructure analysis and corrosion behavior of biodegradable $\mathrm{Mg}$ Ca implant alloys, Mater. Des., 33, 2012, p.88

9. KIRKLAND, N.T., BIRBILIS, N., WALKER, J., WOODFIELD, T., DIAS, G.J ., STAIGER, M.P., In-vitro dissolution of magnesium-calcium binary alloys: Clarifying the unique role of calcium additions in bioresorbable magnesium implant alloys, Journal of Biomedical Materials Research Part B: Applied Biomaterials, 95, B, 2010, p. 91.

10. SUN, Y., ZHANG, B., WANG, Y., GENG, L., JIAO, X., Preparation and characterization of a new biomedical Mg-Zn-Ca alloy, Mater. Des., 34, 2012, p. 58.

11. HOFSTETTER, J., BECKER, M., MARTINELLI, E., WEINBERG, A.M., MINGLER, B., KILIAN, H., POGATSCHER, S., UGGOW ITZER, P.J ., LOFFLER, J.F., High-Strength low-alloy (HSLA) Mg-Zn-Ca alloys with excellent biodegradation performance, JOM, 66, 2014, p. 566.

12. ZHOU, Y., LI, Y., LUO, D., WEN, C., HODGSON P., Microstructures, mechanical properties and in vitro corrosion behaviour of biodegradable Mg-Zr-Ca alloys, J ournal of Materials Science, 48. No.4, 2012, p. 1632.

13. LUPESCU, S., ISTRATE B., MUNTEANU, C., MINCIUNA, M.G., FOCSANEANU, S., EARAR, K., Characterization of Some Master Mg-X System ( $\mathrm{Ca}, \mathrm{Mn}, \mathrm{Zr}, \mathrm{Y}$ ) Alloys Used in Medical Applications, Rev.Chim.(Bucharest), 68, no. 6, 2017, p.1408.

14. CIMPOESU, N., SANDULACHE, F., ISTRATE, B., CIMPOESU, R., ZEGAN, G., Electrochemical Behavior of Biodegradable FeMnSi-MgCa Alloy, METALS, 8, no. 7, 2018, Art. Number: 541.

15. MOHAMED, A., EL-AZIZ, A.M., BREITINGER, H.-G., Study of the degradation behavior and the biocompatibility of $\mathrm{Mg}-0.8 \mathrm{Ca}$ alloy for orthopedic implant applications, Journal of Magnesium and Alloys, 7, no. 2, 2019, p. 249.

Manuscript received:14.05.2019 